\title{
Local Initiatives of Land Rehabilitation in the Sudano-Sahelian Region: Case of Hardé Soils in the Far North Region of Cameroon
}

\author{
Désiré Tsozué $^{* *}$, Bertand Roger Haiwe ${ }^{1}$, Jean Louleo ${ }^{1}$, Jean Pierre Nghonda ${ }^{2}$ \\ ${ }^{1}$ Department of Environmental Sciences, High Institute of the Sahel, University of Maroua, Maroua, Cameroon; ${ }^{2}$ National Institute of \\ Cartography, Yaoundé, Cameroon. \\ Email: tsozudsir@yahoo.fr
}

Received October $25^{\text {th }}, 2013$; revised November $25^{\text {th }}$, 2013; accepted December $4^{\text {th }}, 2013$

Copyright @ 2014 Désiré Tsozué et al. This is an open access article distributed under the Creative Commons Attribution License, which permits unrestricted use, distribution, and reproduction in any medium, provided the original work is properly cited. In accordance of the Creative Commons Attribution License all Copyrights @ 2014 are reserved for SCIRP and the owner of the intellectual property Désiré Tsozué et al. All Copyright (C) 2014 are guarded by law and by SCIRP as a guardian.

\section{ABSTRACT}

Local initiatives of hardé soils rehabilitation in Maroua region have been analyzed. Fieldwork consisted of conducting observations and surveys beside farmers in two study sites, Mizileng and Zokok. Investigations on perception of land degradation signs by farmers show that appearance of encrusted surfaces and loss of vegetation cover are signs more expressed in both study sites. Causes expressed include acceleration of water and wind erosion processes, excessive falling of trees, inappropriate farming techniques and climatic hazards. The main consequences are declining of crop yields, lack of farming land and loss of natural pastures. Rehabilitation actions undertaken by local communities surveyed include earth dikes, tillage including cart or hoe ploughing, application of organic matter, integrating farming techniques such as fallowing, association and rotation of crop, and lastly, parking of animals on plots to be rehabilitated. Populations assert that their majority perceive signs of real change on planning plots in six months to three years. Constraints to those rehabilitation actions include material requirements that are mostly not available or accessible to farmers in the study area and access to land. Globally, there is no integration of local knowledge in the implementation of projects and consequences are localized and ephemeral efficiency, neither conclusive results. Implementation of an innovation in rural areas must take into account the factors of ownership and inscribe a well-defined trajectory. This trajectory must be dynamic and reflexive where local knowledge will cope with expert knowledge to ensure impact and sustainability of innovation.

\section{KEYWORDS}

Local Initiative; Hardé Soils; Land Degradation; Rehabilitation; Cameroon

\section{Introduction}

Sub-Saharan Africa region, especially the Sahel area, experienced a constantly growing degradation of its environmental characteristics since several decades. This degradation is characterized by the deterioration of the major components of the ecosystems such as soil, vegetation and water [1-3]. Among these components, soil degradation or land degradation affects lives and income of millions of people, especially those living in rural ar-

"Corresponding author. eas [4]. This degradation results from climate-induced drought and a variety of unsustainable agricultural and forestry management. In the Far North region of Cameroon, it results in the appearance and expansion of bare and crusted spaces unable to sustain agricultural and pastoral activities [5]. These degraded lands, widespread throughout Sub-Saharan Africa region in general, are known as hardé in the Far North region of Cameroon [68], a term borrowed from Fulfulde language of the Maroua region, equivalent to naga in Chad and zippelé in Burkina Faso. Around 13\% of the total land area in the 
Maroua region is degraded due mainly to mechanized cotton mono-cropping by hundreds of local farmers with fertilizer inputs supplied by the cotton industry, shifting cultivation, overgrazing, over-harvesting of fuelwood, uncontrolled forest fires and high population pressure [4]. According to the level of land degradation, many initiatives have been undertaken for soil rehabilitation. Among them, the most significant initiatives include those of national and international institutions (IRAD and CIRAD respectively), government programs and projects, and at last civil society organizations and national or international NGOs. Those initiatives are mainly improvement of traditional techniques, including bunds, earth dikes, small dams, half-moon, Zaï method or planting holes, mineral fertilizer booster, herbicides, selected seeds and mechanization of hard work and today direct-seeding mulch-based cropping systems (DMC). Despite the robustness of financial and material resources used in the implementation of these initiatives, it is clear that they have localized and ephemeral efficiency, but also inconclusive results $[5,9]$. To cope with this problem, farmers further develop skills learned from their ancestors. Very few studies have been devoted to the role of villager activities, their contributions to the dynamics of hardé soils rehabilitation, whether individual or collective actions. However, some studies on the characterization and rehabilitation trial of these hardé soils have been carried out [5,6,10-13]. However, the question is whether farming communities in the Maroua region can develop actions promoting hardé soils rehabilitation through their own efforts, since modern technologies have inconclusive results. The present work proposes to analyze local initiatives of hardé soils rehabilitation in the Maroua region. That is to identify and describe the local initiatives of hardé soils rehabilitation, to assess the impact of local initiatives on the hardé soils rehabilitation process and finally to evaluate the different constraints related to the implementation of various local techniques of hardé soils rehabilitation across the study area. To do this, two study sites have been selected, Mizileng and Zokok, all located in the Maroua region, in the Far North Region of Cameroon.

\section{Material and Methods}

\subsection{Study Sites}

The study area is located in Maroua, in the Far North Region of Cameroon (Figure 1). It extends globally between $10^{\circ} 23^{\prime} 05^{\prime \prime}$ and $10^{\circ} 42^{\prime} 00^{\prime \prime}$ North and between $14^{\circ} 03^{\prime} 27^{\prime \prime}$ and $14^{\circ} 21^{\prime} 00^{\prime \prime}$ East. The general climate of the region is Sudano-Sahelian [14], characterized by a mean annual rainfall of about $757.2 \mathrm{~mm}$ and a mean annual temperature of about $28^{\circ} \mathrm{C}$. The aridity index of De Mar- tonne (1926) [15] shows a dry season from November to May $(\mathrm{I}<20)$ and a raining season from June to September (I $>20)$ (Table 1$)$. The relief is characterized by the predominance of plains with however some massifs and inselbergs isolated here and there. The vegetation is characterized by shrub savannah locally arboreous with various grasses [16]. The main human activities in the region are agriculture and breeding.

\subsection{Hardé Soills}

Hardé soils are covered by indigent woody vegetation and seasonal sparse grass cover even sometimes nonexistent $[6,8]$. A hardé soil is constituted of a very thin layer of humeferous surface horizon which covers a fairly compact layer $(2-20 \mathrm{~cm}$ to $30 \mathrm{~cm}$ ) impermeable to water and which inhibits the growth of roots [6]. These soils are highly susceptible to erosion, acidic $(5<\mathrm{pH}<6)$ and deprived of exchangeable bases (CEC $=5-10$ meq/100g). But, in degraded vertisols, $\mathrm{pH}$ is near neutrality and CEC can reach $35 \mathrm{meq} / 100 \mathrm{~g}$ [12]. Their texture is sandy-clay in the surface horizon. In depth, clay tends to accumulate and clog the pores. Organic matter content is low $(0.5 \%$ to $1 \%)$ [7]. The wetness of hardé soils rarely exceeds $25 \mathrm{~cm}$. They rarely offer more than two to three months of water availability for vegetation on their whole profile [12].

\subsection{Data Collection}

Fieldwork consisted of conducting observations and surveys beside farmers in the two study sites, Mizileng and Zokok (Figure 1). Approaches used were essentially based on semi-direct interviews. Semi-direct interviews (individual interviews) allow respondents to speak freely on the subject with a minimum intervention of the person conducting the interview. Individuals subjected to the interview were randomly selected. In order to obtain more reliable information, heads of household or individual of age equal or greater than 25 years were chosen. In each site, structured questionnaires, administrated to a sample of 100 farmers, were used to collect qualitative information on the different aspects of hardé soils rehabilitation. The administration of each questionnaire took about one hour for men and more for women. The total survey in both sites was completed after three months. The information collected include perceptions of farmers on land degradation, local knowledge on hardé soils rehabilitation, actions carried up and changes observed, impacts of local initiatives and constraints, knowledge of national and international organizations working for the rehabilitation of hardé soils and their views on the possible role of local actions in the regeneration process of hardé soils in their area. To complete information pro- 


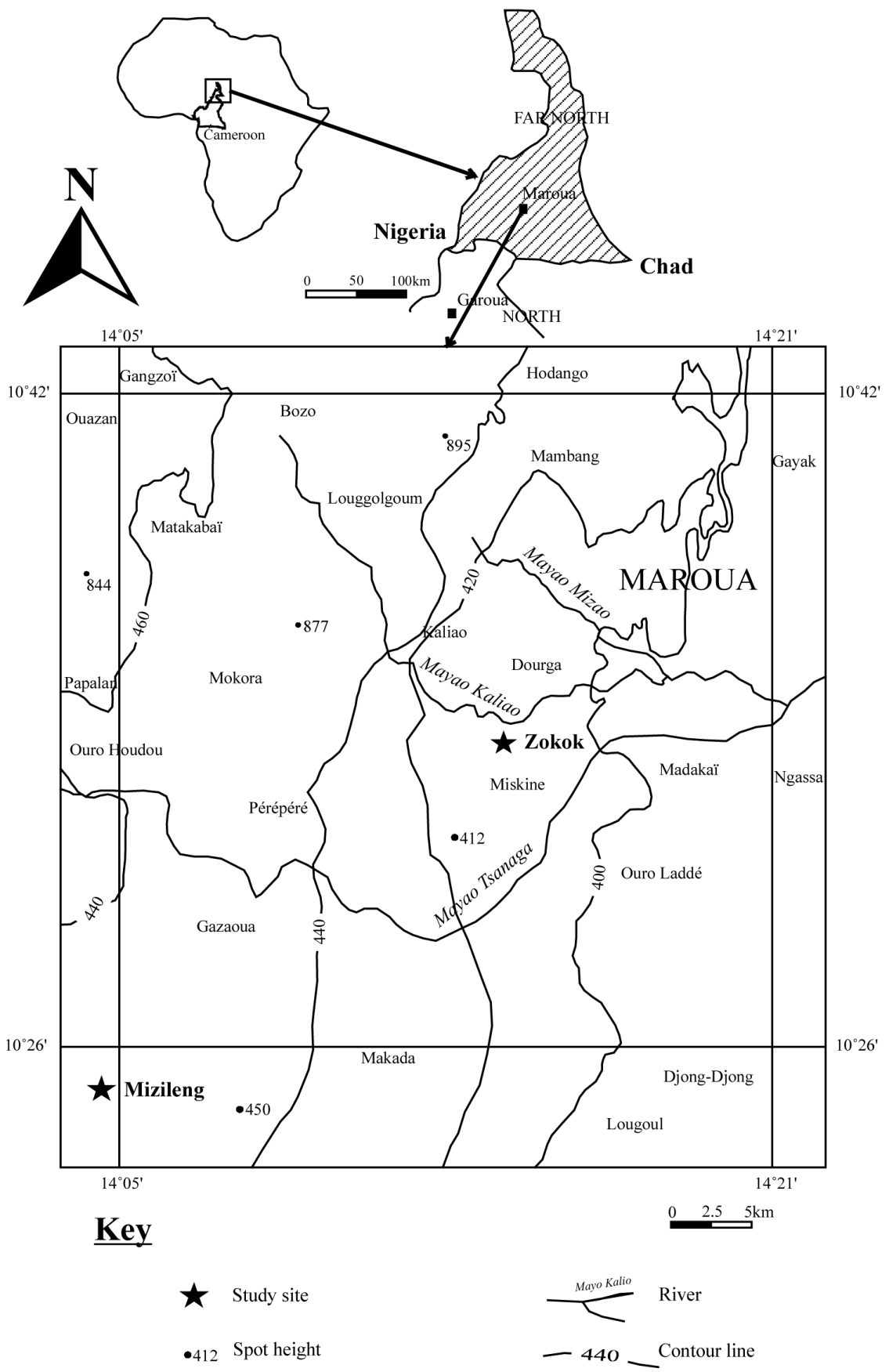

Figure 1. Location of Maroua region.

Table 1. Aridity index of De Martonne (1926).

\begin{tabular}{ccccccccccccc}
\hline & January & February & March & April & May & June & July & August & September & October & November December \\
\hline I & 0 & 0 & 0.8 & 6 & 1.4 & 30.4 & 60.2 & 72.3 & 31 & 6 & 0.1 & 0 \\
\hline
\end{tabular}

vided by the local population, visits were undertaken in the rehabilitated plots and plots being rehabilitated in order to observe the various actions taken by farmers in the different study sites. After data collection, Excel software was used to type and analyse data. All the respondents participated in each questionnaire. In the counting phase, responses were classified and corresponding percentages were calculated, based on the num- 
ber of respondents. In this study, it is about descriptive statistics (frequency and mean essentially).

\section{Results}

\subsection{Perception of Farmers on Land Degradation}

Analysis of farmers' perceptions on land degradation was mainly based on their identification of the signs, the causes and the consequences of land degradation.

\subsubsection{Signs of Land Degradation}

In the localities surveyed, people are unanimous that land resources in their region are deteriorating day after day. This phenomenon is felt through gradual disappearance of vegetation, appearance of encrusted surfaces, low water infiltration and decreasing yields. Figure 2 shows an example of a crusting phenomenon which affects soils surface in the Mizileng site. Herbaceous vegetation is almost nonexistent in the dry season. It is observe nevertheless some thorny as Balanites aegyptiaca and Ziziphus mauritiana.

Investigations on perception of land degradation signs by farmers show that appearance of encrusted surfaces and loss of vegetation cover are signs more expressed by respondents in both study sites (more than $70 \%$ of respondents) (Table 2). However, there are some disparities from one site to another. In Mizileng, crusting of the soil surface is the more expressed sign (93.33\%). This percentage is largely higher than in Zokok (46.67\%) (Table 2). In Zokok on the contrary, the absence of her-

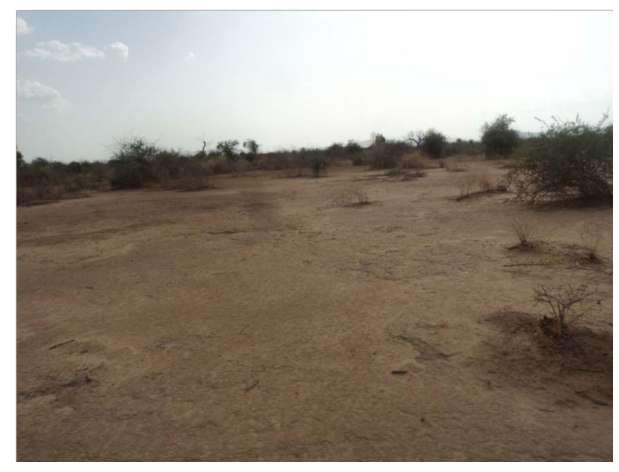

Figure 2. Crusting phenomenon marked by progressive disappearance of herbaceous vegetation.

Table 2. Distribution of respondent according to signs of land degradation.

\begin{tabular}{ccccc}
\hline Localities & $\begin{array}{c}\text { Crusting } \\
\text { surface }\end{array}$ & $\begin{array}{c}\text { Absence of } \\
\text { herbaceous } \\
\text { vegetation }\end{array}$ & $\begin{array}{c}\text { Low water } \\
\text { infiltration }\end{array}$ & $\begin{array}{c}\text { Decreasing } \\
\text { yield }\end{array}$ \\
\hline Mizileng & $93.33 \%$ & $86.67 \%$ & $13.33 \%$ & $6.67 \%$ \\
Zokok & $46.67 \%$ & $80 \%$ & $13.33 \%$ & $26.67 \%$ \\
Mean & $70 \%$ & $83.33 \%$ & $13.33 \%$ & $16.67 \%$ \\
\hline
\end{tabular}

baceous vegetation is highly expressed (80\%). This percentage, although quite high, stills lower than in Mizileng (80\% in Zokok compared to $86.67 \%$ in Mizileng) (Table 2). Low water infiltrability and low yields are less expressed, resulting probably from the first two signs.

\subsubsection{Causes and Consequences of Land Degradation} In addition to the identification of signs of land degradation, local people also highlighted knowledge on the causes and consequences of this phenomenon. The causes of land degradation expressed by respondents are notably the acceleration of water and wind erosion process, abusive falling of trees, inappropriate farming techniques and climatic hazards.

Processes of water and wind erosion are the most common causes expressed by the populations surveyed (60\% in both sites) (Table 3). Inappropriate farming techniques and abusive wood cutting are weakly expressed. Abusive cutting of wood is brought out by $16.5 \%$ respondents (Table 3). Inadequate farming techniques are raised by $33 \%$ of respondents in Mizileng contrary to Zokok where this factor is not a major cause of land degradation (Table 3). However, a significant percentage of people in Zokok (20\%) refer to climatic hazards as one of the causes of land degradation (Table 3).

The main consequences of the phenomenon expressed by respondents are declining of crop yields (60\% in Mizileng compared to $33 \%$ in Zokok), lack of farming land (33\% in Mizileng compared to 73\% in Zokok) and decline in pastoral activity (13\% in Mizileng compared to $33 \%$ in Zokok) (Table 3). In total, the lack of farming land is the consequence most expressed by people (53\%), closely followed by lower yields (46.5\%) in the Maroua region (Table 3). In general, except for lower yields, consequences are stronger expressed in Zokok than in Mizileng.

\subsection{Local Knowledge}

The main local knowledge techniques outlined by the farmers surveyed are earth dikes, tillage including cart or hoe ploughing, spreading of organic matter (Figure 3(a)), integration farming techniques such as fallowing, association and rotation of crop (Figures 3(a) and (b)), and at last practice of parking animals on plots to be rehabilitated. Organic matter is mainly composed of animal manure, crop residues and sometimes organic household waste. Figures 3(a) and (b) show plots of hardé rehabilitated in order to cultivate on which farmers chose to do rotation of cotton/sorghum. Tillage and spreading of organic matter are local knowledge most often mentioned by respondents ( $90 \%$ for tillage and $80 \%$ for the spreading of organic matter on average) (Table 4). Integration 
Table 3. Distribution of respondent according to causes and consequences of land degradation.

\begin{tabular}{cccccccc}
\hline \multirow{2}{*}{ Localities } & \multicolumn{3}{c}{ Causes } & \multicolumn{3}{c}{ Consequences } \\
\cline { 2 - 8 } & Erosion & $\begin{array}{c}\text { Abusive cutting } \\
\text { of trees }\end{array}$ & $\begin{array}{c}\text { Inappropriate } \\
\text { farming techniques }\end{array}$ & Climatic hazards & $\begin{array}{c}\text { Declining of } \\
\text { crop yields }\end{array}$ & $\begin{array}{c}\text { Lack of farming } \\
\text { land }\end{array}$ & $\begin{array}{c}\text { Decline of } \\
\text { pastoral activity }\end{array}$ \\
\hline Mizileng & $60 \%$ & $13 \%$ & $33 \%$ & $0 \%$ & $60 \%$ & $33 \%$ & $13 \%$ \\
Zokok & $60 \%$ & $20 \%$ & $0 \%$ & $20 \%$ & $33 \%$ & $73 \%$ & $33 \%$ \\
Mean & $60 \%$ & $16.5 \%$ & $16.5 \%$ & $10 \%$ & $46.5 \%$ & $53 \%$ & $23 \%$ \\
\hline
\end{tabular}

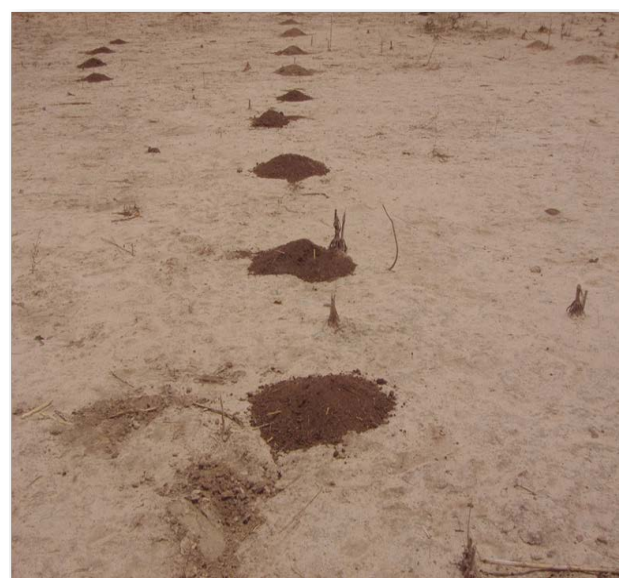

(a)

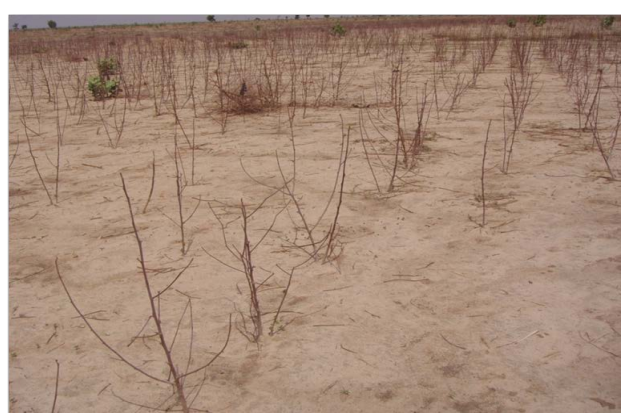

(b)

Figure 3. Hardé soil being rehabilitated on which cotton/ sorghum rotation is conducted: (a) With sorghum stem and spreading of animal manure; (b) With cotton stem.

Table 4. Distribution of respondent according to local knowledge expressed.

\begin{tabular}{cccccc}
\hline Localities & $\begin{array}{c}\text { Earth } \\
\text { dikes }\end{array}$ & $\begin{array}{c}\text { Spreading of } \\
\text { organic } \\
\text { matter }\end{array}$ & Tillage & $\begin{array}{c}\text { Integration } \\
\text { farming } \\
\text { techniques }\end{array}$ & $\begin{array}{c}\text { Parking of } \\
\text { animals }\end{array}$ \\
\hline Mizileng & $40 \%$ & $67 \%$ & $100 \%$ & $27 \%$ & $53 \%$ \\
Zokok & $20 \%$ & $93 \%$ & $80 \%$ & $33 \%$ & $0 \%$ \\
Mean & $30 \%$ & $80 \%$ & $90 \%$ & $30 \%$ & $26.5 \%$ \\
\hline
\end{tabular}

of farming techniques, implementation of earth dikes and parking of animal techniques are on the contrary, the least outlined. However, they are quite significant, since they are mentioned by $\sim 30 \%$ of the population on average, but are expressed differently from one site to an- other (Table 4).

Implementation of local knowledge passes necessarily by a perfect mastery of them. A farmer may have knowledge in soil rehabilitation but be unable to materialize it as tangible actions in the farm. Tillage and supply of organic matter are by far the most mastered local knowledge expressed by respondents (66.5\% and $86.5 \%$ respectively on average in both sites) (Table 5). Integration of farming techniques, parking of animals and earth dikes are the least mastered techniques. Among these, integration of farming techniques is quite mastered in the two sites, while parking of animals and earth dikes are quite mastered exclusively in Mizileng site (Table 5).

\subsection{Actions and Changes Observed}

Rehabilitation of hardé soils is then possible as a result of a combination of local techniques and consistent community mobilization. Spreading of organic matter and tillage appear as the most actions carried out during the rehabilitation of the hardé soil (Table 6). They are done by more than $75 \%$ of respondents and are globally more applied in Zokok than in Mizileng (Table 6). Implementation of earth dikes is weakly carried out (23\% on average) (Table 6). Parking of animals is practiced only in Mizileng (33\%) (Table 6). Integration of farming techniques namely crop fallow, association and rotation of crop during rehabilitation activities, is weakly practiced in the two study sites (26.5\% on average) (Table 6). However, it appears that this practice is more widespread in Zokok (40\%) than in Mizileng (13\%).

Populations in the study area that invest in actions of hardé rehabilitation for farming estimate in their majority that a period of 6 months to 3 years is sufficient to perceive signs of a real change on planning plots. These signs allow them to deduce that these plots are being rehabilitated. The most visible signs mentioned by respondents are the return of herbaceous vegetation, changing in colour and structure of soils (Table 6). The return of the herbaceous vegetation is more expressed in Zokok than in Mizileng (Table 6). The change in colour of the soil is raised by $50 \%$ of the study population. As for the change in soil structure marked by a higher infiltration of water into the soil, it is expressed by $53 \%$ of respondents (Table 6). 
Table 5. Distribution of respondent according to local knowledge mastered.

\begin{tabular}{cccccc}
\hline Localities & Earth dikes & $\begin{array}{c}\text { Spreading of organic } \\
\text { matter }\end{array}$ & Tillage & $\begin{array}{c}\text { Integration farming } \\
\text { techniques }\end{array}$ & Parking of animals \\
\hline Mizileng & $27 \%$ & $93 \%$ & $80 \%$ & $20 \%$ & $33 \%$ \\
Zokok & $13 \%$ & $80 \%$ & $53 \%$ & $27 \%$ & $0 \%$ \\
Mean & $20 \%$ & $86.5 \%$ & $66.5 \%$ & $23.5 \%$ & $16.5 \%$ \\
\hline
\end{tabular}

Table 6. Distribution of respondent according to actions carried out during rehabilitation processes and signs of change observed on planning plots.

\begin{tabular}{|c|c|c|c|c|c|c|c|c|}
\hline \multirow[b]{2}{*}{ Localities } & \multicolumn{5}{|c|}{ Actions carried out during rehabilitation processes } & \multicolumn{3}{|c|}{ Change observed on planning plots } \\
\hline & Earth dikes & $\begin{array}{l}\text { Spreading of } \\
\text { organic matter }\end{array}$ & Tillage & $\begin{array}{l}\text { Integration farming } \\
\text { techniques }\end{array}$ & $\begin{array}{l}\text { Parking of } \\
\text { animals }\end{array}$ & $\begin{array}{l}\text { Return of herbaceous } \\
\text { vegetation }\end{array}$ & $\begin{array}{l}\text { Changing in } \\
\text { soil colour }\end{array}$ & $\begin{array}{l}\text { Changing in } \\
\text { soil structure }\end{array}$ \\
\hline Zokok & $13 \%$ & $86 \%$ & $80 \%$ & $40 \%$ & $0 \%$ & $67 \%$ & $53 \%$ & $53 \%$ \\
\hline Mean & $23 \%$ & $79.5 \%$ & $76.5 \%$ & $26.5 \%$ & $16.5 \%$ & $53.5 \%$ & $50 \%$ & $53 \%$ \\
\hline
\end{tabular}

\subsection{Impacts of Local Initiatives and Constraints}

The direct effect of rehabilitation actions of hardé soils is felt mainly on agricultural income of different households surveyed. Thus, $87 \%$ of respondents say that the actions have an impact on agricultural income which increases gradually while $13 \%$ say that they feel no direct effects of actions, which result in a failure. The respondents were unanimous on the important role that local knowledge can play in the regeneration process of hardé soils in the Maroua region. This view is shared by $60 \%$ of respondents in Zokok, whereas in Mizileng, all the respondents are almost unanimous (93\%).

Implementation of villagers' actions generates material requirements that are mostly not available or accessible to farmers in the study area. Tillage requires the use of tools such as cart, animals for ploughing or heavy equipment to ensure subsoiling. Consequently, the poorest farmers cannot get most of the tools mentioned. They are therefore forced to hire someone services or invest themselves manually with simple tools such as hoes, pickaxes, crowbars, which make the works very hard.

The availability of organic matter is a major obstacle to the cultivation of hardé soils. This implies that farmers should have either a heap manure barn or financial means to buy it. Those who do not have enough animals for example usually associate organic household waste. The problem of availability of organic matter is expressed by $66.5 \%$ of the study population (Table 7 ).

Construction of earth dikes and breaking of crust are actions that usually require high human intervention, so a substantial manual labour. To rehabilitate a large area, a farmer is forced to call for other people, often paying manual labour that is in most cases inaccessible to poor individuals. Thus, in the Mizileng site, $87 \%$ of those surveyed believe that manual labour is a limiting factor
Table 7. Constraints linked to local actions carried out.

\begin{tabular}{ccccc}
\hline Localities & Hard labour & $\begin{array}{c}\text { Availability of } \\
\text { organic matter }\end{array}$ & $\begin{array}{c}\text { Access to } \\
\text { land }\end{array}$ & Material \\
\hline Mizileng & $87 \%$ & $73 \%$ & $33 \%$ & $13 \%$ \\
Zokok & $46 \%$ & $60 \%$ & $46 \%$ & $13 \%$ \\
Mean & 66.5 & $66.5 \%$ & $39.5 \%$ & $13 \%$ \\
\hline
\end{tabular}

to the implementation of local rehabilitation techniques. In Zokok on contrary, this factor is expressed by $46 \%$ of respondents (Table 7).

Access to land is considered as one of the social constraints to farmers' actions in the rehabilitation of hardé soils (Table 7). The interest of farmers to rehabilitate a hardé soils depends highly on whether they are owner or not. If a farmer is owner, he is able to consent his time and considerable effort to rehabilitate it. In the case of leasing, a farmer is often afraid of losing a parcel on which he gave his energy and time to rehabilitate.

\subsection{Knowledge of National and International Organizations Working for the Rehabilitation of Hardé Soils}

Field surveys have permitted to notice that just $7 \%$ of the study population reported having knowledge of the existence of organizations working on the rehabilitation of hardé soils across the study area. The latter evoke the case of Water-Soil-Tree project of SODECOTON (Cotton Development Company in Cameroon), which one of the means of intervention was the distribution of grains of herbaceous species such as Brachiaria sp. intended to be sown in degraded parcels in order to restore their fertility. However, interviews of people made in the study area show a real desire to create associations in order to give a certain efficacy to local actions. 


\section{Discussion}

The results of the study revealed that tillage, supply of organic manure, establishment of earth dikes, parking of animals, integration of farming techniques are the main techniques used by local people. They will be analysed in order to contribute to solve the problem of land degradation in Maroua region.

\subsection{Local Rehabilitation Techniques of Hardé Soils}

\subsubsection{Tillage}

Advantages of tillage have been reported by several studies conducted in the framework of the rehabilitation of hardé soils. Ploughing helps to break soil crust, thus increasing the infiltration potential of water and the hydrodynamic properties of the soil as well $[12,17]$. Tillage is mainly done using a set of light materials and subsoiling is not widespread in the study area. This confirms the results of Eyog-Matig (1993) [17] who showed that this technique, because of its expensive character, is not applicable in rural areas. Farmers choose simple and rudimentary means to rehabilitate hardé soils, which involve hard work, limiting consequently their ambition in rehabilitating larger areas. Techniques of Zaï and half-moon, widespread in West Africa are not common in the study sites. Though, the positive impact of Zaï soils recuperation and revegetation has been highlighted in several studies [4]. Its application to encrusted surfaces, highly degraded, constitute a simple solution of land productivity restoration and agro-forestry rehabilitation [18]. Beyond these techniques used in West Africa, traditional and innovative techniques are widely used in other countries, as example of DMC. The main feature is no-till cropping and permanent soil protection with both crop residues and companion crops, through crop combination, yearly sequences or rotation [19]. It improves the structural soil surface through the increasing of macroporosity, the decrease of soil compaction, strengthening of the structural index after 1 - 9 years and over according to the technique [20-24].

\subsubsection{Supply of Organic Matter}

Supply of organic manure is the most common technique used and mastered by farmers in the study area. This reflects the fact that respondents recognize the value of improving hardé soils fertility through the increase of their organic matter content as already reported by many authors $[11,25,26]$. However, if the organic manure appears to be a accommodate solution, the problem of its production in farmers' environment remains unsolved [27]. Similarly, investigations on various constraints related to the implementation of local actions in soil reha- bilitation show that in Mizileng and Zokok sites the availability of organic manure remains a limiting factor.

There are other possibilities for improving the organic status of hardé soils. It is among other things mulching techniques, improved fallow, planting legumes or introduction of DMC. The integration of these techniques could contribute to both the return of the organo-mineral horizon and the limitation of the action of erosion on the soil surface [25]. There are also opportunities to transform household organic waste and crop residues into compost. The compost produced could be a palliative solution for the problem of animal manure availability. Similarly, the application of mineral fertilizer in addition to organic manure has been shown to have significant effects on the process of hardé soils rehabilitation, but the question of its accessibility in rural environment remains a constraint to its adoption [26]. Compost provides efficient nitrogen compounds, phosphorus, potassium and trace elements in soil and plant $[23,28]$.

\subsubsection{Establishment of Earth Dikes Network}

Establishment of earth dikes network is not widespread in the two study sites. Though, many studies have shown the importance of this technique in the rehabilitation of hardé soils in the Maroua region [5,8]. Earth dikes networks prevent runoff of rainwater and force it to soak in soils naturally with low permeability, promoting thus the development of grasses during the rainy season [5]. However, construction of earth dikes requires considerable investment in time and energy. The application of this technique is therefore influenced by the availability of manual labour and materials needed for its realization. Earth dikes have the disadvantage of being easily destroyed by run-off and first rains crusting, except in the case of planning watershed. This results in the need to maintain them over the years.

\subsubsection{Integration of Farming Techniques}

Integrating farming techniques namely fallow, association and rotation of crops is weakly practiced during the rehabilitation of hardé soils in both study sites. The absence of fallow is due to the lack of suitable areas for cultivation [29]. Undeniably, the long fallow improves the physical, chemical and biological soil properties, but gain in production is low facing the extent of immobilized land. In addition, grazing and fire, frequent on fallow in the Sudano-Sahelian zone, still delay the accumulation process of fertility in the surface horizons. Generally, the cropping system consisting of multi-species and two-species associations are old and have been developed on all continents. It concerns practically all the ecosystems without any exclusive [30,31]. This technique therefore requires improvement to meet the expec- 
tations of the people who will implement it. The integration of DMC currently experienced by SODECOTON [19], would greatly contribute to the increase in farm biomass and yields. This new approach will certainly lead people to be more interested in this technique.

\subsubsection{Animal Parking}

The system of field's fertilisation by providing organic manure is relatively well known. Organic manure is prepared and applied in three forms: stalling of animals in the concession, nocturnal stalling with attached to the field and extensive animal parking [26,32-34]. When animals are stalling in the concession, dried night soil is obtained. In this practice, transport cost to the field is high. In nocturnal stalling with attached to the field, the manure produced consists of supply of dejection and urine deposited, mixed with sand, where animals are tied. This practice also requires a lot of work that is cut, lay, and transfer of pegs [34]. Extensive animal parking is done after harvest. As long as crop residues persist, livestock stays day and night in the fields. Once this reserve is exhausted, herds that graze during the day in fallows and on plateaus, return to the fields at night. Dung dries in place and remains entirely unmixed with urine [34]. This third form of application of manure is by far the most widespread in the region [34]. Studies that determine the amount of manure deposited annually in the fields, give low deposits, but often highly varied $[34,35]$. However, high levels of organic matter reduce the wettability of the aggregates by hydrophobic agent and therefore the risk of bursting during dampening, contributing thus to an improvement of the soil surface structure $[27,32,34]$. The lack of animals parking in Zokok is due to the proximity of the urban area which leads farmers to move further away large herds. This reopens the debate on the joint evolution of agriculture and livestock at the regional level suggested by many authors in West Africa [32]. However, the densification of the occupation of rural areas resulting in population growth in the Maroua region challenges the technical complementarities between agriculture and livestock. This densification results then in medium-dated in a diminishing of animal's number, involving in its turn the decline of animal fertilization and degradation of agricultural soils [32].

\subsection{Analysis of Constraints to the Implementation of the Local Actions}

From analysis of factors limiting the local actions of hardé soils rehabilitation, it emerges that when needs in manual labour, organic manure and work equipment are more important, less the technique is applied. Hard soil working with light materials is a major constraint. People therefore choose techniques that seem to be the easiest, inexpensive in time and energy and do not require heavy equipment. The rehabilitation of a hardé soils plot is also highly dependent on the access to land. Farmers' interest in the rehabilitation of hardé soils strongly depends on the mode of tenure. When they are owners, they agree to invest in implementing the various actions of rehabilitation. On the contrary, the farmer cannot improve the land for fear of losing the operating license for attempt to appropriation or see the rental price increase in relation to the improvement of soil fertility in the exploitation [4, 36].

\subsection{Analysis of Organizational Capacity}

Analysis of the survey results relating to organizational capacity of rural communities and the existence of organizations that can assist them in the implementation of different actions show a lack of organization within the community. Similarly, the study reveals that $93 \%$ of the study population are totally unaware of the existence of organizations or endogenous and exogenous associations working in the field of hardé soils rehabilitation. Each farmer conducts its activities independently and isolated from others. Though Seignobos (1993) [8] pointed out that the turning to profit of hardé soils must necessarily be collective in one or more land since it imposes changes pasture's habits. The absence of organisms that can supervise or coordinate the villagers' rehabilitation actions has a significant impact on the adoption of certain rehabilitation methods which efficacy has been proven in other lands. This means that there is no integration of local knowledge in the implementation of the project and the direct consequences are localized and ephemeral efficiency, but also not conclusive results. A study made by Kinane et al. (2007) [37] showed that belonging to a farmer organization is fundamental for the adoption of a technique. Construction of earth dikes for example requires a significant investment in time and materials, which can be a real handicap for some farmers. This handicap could be quickly filled by the support system commonly used in the region.

\subsection{Need for an Integrated Approach for Hardé Soils Rehabilitation}

Local techniques discussed here ultimately contribute to the rehabilitation of soil fertility through improving of their physical, chemical and biological properties. Integration of new approaches in order to effectively rehabilitate the soil proves to be necessary. But the implementation of an innovation in rural areas must take into account the factors of ownership and inscribe in a welldefined trajectory. This trajectory must be dynamic and reflexive where local knowledge will be associated with 
expert knowledge to ensure impact and sustainability of innovation [38]. The contribution of organic matter seems to be a unifying element, which has an influence on different soil properties. How can one bring organic matter in the Sahel area so as to circumvent the difficulties posed by these local techniques? The contribution of DMC developed by CIRAD researchers seems to be a best solution. Vegetation cover protects the soil against erosion, increases infiltration through the absence of tillage, reduces evaporation, reduces variations in soil temperature, creates a favourable environment for the development of biological activities, control weeds and increase soil organic matter content [19]. Besides these benefits, it plays an important role in the biogeochemical cycling of elements, and could be a useful forage value for livestock in inter-culture [19]. However, the sustainability and adaptability of technical changes go through awareness-raising and thus empowerment of stakeholders.

\section{Conclusion}

The present study aimed to analyze local actions of hardé soils rehabilitation in the Maroua region. The results of the fieldwork showed that rural populations of Mizileng and Zokok have a good knowledge of signs of land degradation. They are also able to identify the main causes of the phenomenon and the effects on their lives and income. Application of organic manure and tillage are rehabilitation techniques most mastered by respondents, and therefore the most applied. Implementation of earth dikes, bunds, integration of farming techniques and parking of animals are very poorly adopted. The use of mineral fertilizer is not highly widespread in both sites. The main visible signs of hardé soils rehabilitation mentioned by respondents are the return of herbaceous vegetation, the change in soil structure and soil colour. The direct effect of rehabilitation techniques used is then felt primarily on farm income of different households surveyed. The main constraints highlighted by farmers are need in manual labour, organic manure and appropriate equipments, and access to land. The study also reveals almost no organization involved in coaching local actions. Various development partners must truly be involved in the rehabilitation process of hardé soils through training and technical supervision of farmers, for better adoption of innovative techniques as direct-seeding mulch-based cropping systems whose positive effects on land degradation have been proved.

\section{REFERENCES}

[1] H. I. D. Vierich and W. A. Stoop, "Changes in West African Savannah Agriculture in Response to Growing
Population and Continuing Low Rainfall,” Agriculture, Ecosystems and Environment, Vol. 31, No. 2, 1990, pp. 115-132.

http://dx.doi.org/10.1016/0167-8809(90)90214-X

[2] E. M. A. Smaling, S. M. Nandwa and B. H. Janssen, "Soil Fertility in Africa is at Stake,” In: R. J. Buresh, P. A. Sanchez, F. Calhoun, Eds., Replenishing Soil Fertility in Africa, Soil Science Society of America, Madison, 1997, pp. 47-62.

[3] A. Bationo, F. Lompo and S. Koala, "Research on Nutrient Flows and Balances in West Africa: State-of-the-Art," Agriculture, Ecosystems and Environment, Vol. 71, No. 1-3, 1998, pp. 19-35. http://dx.doi.org/10.1016/S0167-8809(98)00129-7

[4] D. Blay, E. Bonkoungou, S. Chamshama and B. Chikamai, "Rehabilitation of Degraded Lands in Sub-Saharan Africa: Lessons Learned from Selected Case Studies,” IUFRO-SPDC, FORNESSA, 2004.

[5] R. Peltier, "Les Terres Hardé. Caractérisation et Réhabilitation dans le Bassin du Lac Tchad”, Montpellier, CIRAD-Forêt, Cahiers Sc. No. 11, 1993.

[6] M. Gavaud, "Les Sols Hardés du Nord-Cameroun (Sols Halomorphes, Sols Lessivés, Planosols, Sols Hydromorphes). Mise au Point Bibliographique,” Bull Liais Thème $\mathrm{B}, 1971$.

[7] P. Brabant and M. Gavaud, "Les Sols et Ressources en Terres du Nord-Cameroun. Carte et Notice Explicative No. 103,” MESRES-IRA, Yaoundé, ORSTOM, Paris, 1985.

[8] C. Seignobos, "Hardé et Karal du Nord-Cameroun: Leur Perception par les Populations Agropastorales du Diamaré,” In: Les Terres Hardé, Caractérisation et Réhabilitation dans le Bassin du Lac Tchad, Mémoires et Travaux de l'Ira No. 6, Cahiers Scientifiques No. 11, Ira-Orstom-Cirad, Montpellier, 1993, pp. 9-28.

[9] R. Guis, "Un Bilan des Travaux Visant à la Mise en Culture des Sols Hardé du Nord Cameroun,”Agronomie Tropicale, Vol. 31, No. 2, 1976, pp. 141-158.

[10] J. Vaille, "Essais de Mise en Valeur des Sols 'Hardés' du Nord-Cameroun,” Agron. Trop., Vol. 25, No. 5, 1970, pp. 472-490.

[11] D. Masse, C. Floret, R. Pontanier and L. SeinyBoukar, "Amélioration du Régime Hydrique des Vertisols Dégradés du Nord Cameroun en Vue de leur Réhabilitation,” Cahiers ORSTOM, Série Pédologie, Vol. 28, No. 2, 1993, pp. 127-137.

[12] L. Seiny-Boukar and R. Pontanier, "Hydrodynamique d'un Sol Hardé du Nord-Cameroun, Caractéristique Comportement," In: Les terres Hardé, Caractérisation et Réhabilitation dans le Bassin du Lac Tchad, Mémoires et Travaux de l'Ira No. 6, Cahiers Scientifiques No. 11, Ira-Orstom-Cirad, Montpellier, 1993, pp. 37-42.

[13] J. Seghieri and C. Floret, "Dynamique Saisonnière de la Végétation en Savane Sahélo-Soudanienne, le Cas des Sols Hardé," In: Les Terres Hardé, Caractérisation et Réhabilitation dans le Bassin du Lac Tchad, Mémoires et Travaux de l'Ira No. 6, Cahiers Scientifiques No. 11, Ira-Orstom-Cirad, Montpellier, 1993, pp. 55-64. 
[14] J. B. Suchel, "Les Climats du Cameroun,” Thèse Doctorat, Université de Bordeaux III, France, 1987.

[15] E. De Martonne, “Aréisme et Indice d'Aridité,” Comptes Rendus Académie des Sciences, Vol. 181, 1926, pp. 13951398.

[16] R. Letouzey, "Notice de la Carte Phytogéographique du Cameroun au 1: 500000. Domaine Sahélien et Soudanien,” Herbier National IRA, Yaoundé, Institut de la Carte Internationale de la Végétation, Toulouse, 1985.

[17] O. Eyog Matig, “Modification du Régime Hydrique d’un Sol par les Aménagements de Surface. Le Cas du Sol Hardé de Salak," In: Les Terres Hardé, Caractérisation et Réhabilitation dans le Bassin du Lac Tchad, Mémoires et Travaux de l'Ira No. 6, Cahiers Scientifiques No. 11, IraOrstom-Cirad, Montpellier, 1993, pp. 99-110.

[18] E. Roose, V. Kabore and C. Guénat, "Le Zaï: Fonctionnement, Limites et Améliorations d'une Pratique Africaine de Réhabilitation de la Végétation et de la Productivité des Terres Dégradées en Région Soudano-Sahélienne (Burkina Faso)," Cahiers Orstom, Série Pédologie, Vol. 28, No. 2, 1993, pp. 159-173.

[19] Comité Scientifique Français de la Désertification, "Lutte Contre la Désertification: l'Apport d'une Agriculture en Semis Direct sous Couverture Végétale (SCV)," Les dossiers Thématiques, No. 4, CSFD/Agropolis International, 2006.

[20] S. Hernando, M. Lobo and A. Polo, "Effect of the Application of a Municipal Refuse Compost on the Physical and Chemical Properties of Soil," Science of the Total Environment, Vol. 81-82, 1989, pp. 589-596. http://dx.doi.org/10.1016/0048-9697(89)90167-8

[21] B. Singh Sing, D. S. Chanasyk and W. B. McGill, "Soil Hydraulic Properties of an Orthic Black Chernozem under Long-Term Tillage and Residue Management," Canadian Journal of Soil Science, Vol. 76, No. 1, 1996, pp. 63-71.

[22] B. Barthès, A. H. Azontondé, B. Z. Boli, C. Prat and E. Roose, "Field-Scale Runoff and Erosion in Relation to Topsoil Aggregate Stability in Three Tropical Regions (Bénin, Cameroon, Mexico),” European Journal of Soil Science, Vol. 51, No. 3, 2000, pp. 485-495. http://dx.doi.org/10.1046/j.1365-2389.2000.00322.x

[23] M. D. Soumaré, P. N. S. Menkeni and M. Khouma, "Effects of Casuarina Equisetifolia Composted Litter and Ramial-Wood Chips on Tomato Growth and Soil Properties in Niayes, Senegal,” Biological Agriculture and Horticulture, Vol. 20, No. 2, 2002, pp. 111-123. http://dx.doi.org/10.1080/01448765.2002.9754955

[24] M. Annabi, S. Houot, C. Francou, M. Poitrenaud and Y. LeBissonnais, "Soil Aggregate Stability Improvement with Urban Composts of Different Maturities," Soil Science Society of America Journal, Vol. 71, No. 2, 2007, pp. 413-423. http://dx.doi.org/10.2136/sssaj2006.0161

[25] E. Roose, "Présentation: Innovations dans la Conservation et la Restauration des Sols," Cahiers Orstom, Série Pédologie, Vol. 28, No. 2, 1993, pp. 147-155.

[26] D. Masse, “Changements d'Usage des Terres dans les Agro-Systèmes d'Afrique Sub-Saharienne. Propriétés des
Sols et Dynamique des Matières Organiques,” Mémoire HDR, Institut National Polytechnique de Toulouse, Ecole Nationale Supérieure Agronomique de Toulouse, France, 2007.

[27] C. Pieri, “Fertilité des Terres de Savanes. Bilan de 30 Années de Recherche et Développement Agricole au Sud du Sahara," Ministère de la Coopération et du Développement, CIRAD, Paris, 1989.

[28] M. Zhang, D. Heaney, B. Henriquez, E. Solberg and E. Bittner, "A Four-Year Study on Influence of Biosolids/ MSW Compost Application in Less Productive Soils in Alberta: Nutrient Dynamics,” Compost Science \& Utilization, Vol. 14, No. 1, 2006, pp. 68-80. http://dx.doi.org/10.1080/1065657X.2006.10702265

[29] A. P. K. Gomgnimbou, P. W. Savadogo, A. J. Nianogo and J. Millogo-Rasolodimby, "Pratiques Agricoles et Perceptions Paysannes des Impacts Environnementaux de la Cotonculture dans la Province de la Kompienga (Burkina Faso)," Sciences \& Nature, Vol. 7, No. 2, 2010, pp. 165175. http://dx.doi.org/10.4314/scinat.v7i2.59960

[30] K. N'Goram and J. Snoeck, "Cultures Vivrières Associées au Caféier en Côte d'Ivoire (Food Crops Intercropping with Coffee Trees in Ivory Coast)," Café, Cacao, Thé, Vol. 31, No. 2, 1987, pp. 121-133.

[31] C. Baldy and C. J. Stigter, "Agrometeorology of Multiple Cropping in Warm Climate,” INRA, Paris, 1997.

[32] E. Landais and P. Lhoste, "Systèmes d'Elevage et Transferts de Fertilité dans la Zone des Savanes Africaines, II. Les Systèmes de Gestion de la Fumure Animale et leur Insertion dans les Relations entre l'Elevage et l'Agriculture,” Cahiers Agricultures, Vol. 2, 1993, pp. 9-25.

[33] J. M. Powell, S. Fernàndez-Rivera, P. Hiernaux and M. D. Turner, "Nutrient Cycling in Integrated Rangeland/Cropland Systems of the Sahel,” Agricultural Systems, Vol. 52, No. 2-3, 1996, pp. 143-170. http://dx.doi.org/10.1016/0308-521X(96)00009-1

[34] A. De Rouw, “Comment Assurer la Production de Mil: Jachère ou Parcage? Amélioration de la Jachère en Afrique de l'Ouest,”Atelier Jachères et Systèmes Agraire, Niamey, 1998, pp. 141-152.

[35] J. P. Qu1lfen and P. Milleville, "Résidus de Culture et Fumure Animale: un Aspect des Relations AgricultureElevage dans le Nord de la Haute-Volta,” Agronomie Tropicale, Vol. 38, 1983, pp. 206-212.

[36] FAO, "World Reference Base for Soil Resources,” World Soil Resources Report, No. 84, ISSS, ISRIC and FAO, Rome, 1998.

[37] M. L. Kinané, M. Koné and A. Sidibé, "Perception de la Dégradation des Terres et Adoption des Technologies de Conservation des Eaux et des Sols au Nord du Burkina Faso : le cas du Zaï et des Cordons Pierreux,” Agriculture and Sustainable Development, AAAE Conference Proceedings, Ghana, 2007, pp. 543-548.

[38] A. Floquet, "A l'Echelle d'une Vie: Trajectoires et Décisions Paysannes au Bénin,” In: M. Gafsi, P. Dugué, J. Y. Jamin and J. Brossier, Eds., Exploitation Agricoles Familiales en Afrique de l'Ouest et du Centre, Quae, Versailles, 2007, pp. 195-212. 